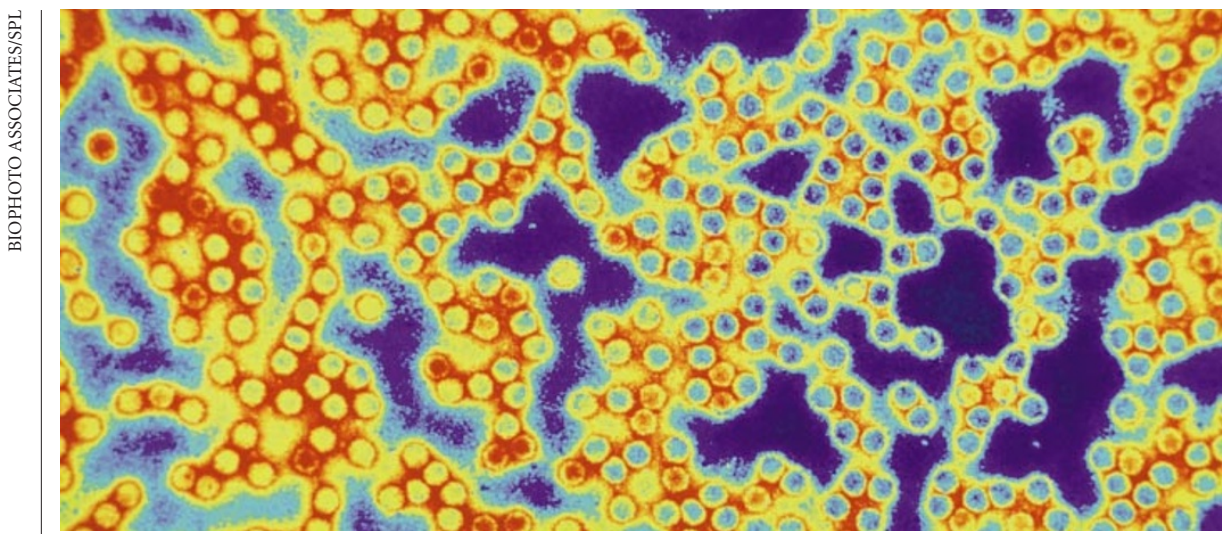

Fighting back: a wild virus strain from India has given Europe its first polio cases for two years.

\title{
Plans to eradicate polio hit by virus outbreak in Bulgaria
}

Mark Schrope

Two new cases of poliomyelitis in Bulgaria threaten to delay plans by the World Health Organization (WHO) to eradicate the disease from the planet. The cases raise particular concern because they are caused by a wild virus, rather than by the strain used in vaccinations.

There had been no reported cases of polio in Europe for more than two years. But in March a girl in the Bulgarian seaport of Burgas was paralysed by the disease, and a second case of paralysis was confirmed in the area on 11 May.

Researchers say the outbreak sends a warning to countries around the globe to maintain their guard against polio, despite the rapid decline in its incidence. Bulgaria had not had a case of polio caused by wild virus for almost ten years.

Gene sequences of the strain responsible match a wild strain from India. "It is a matter of real concern whenever you have importation into a disease-free area," says Donald Henderson, an epidemiologist at Johns Hopkins University in Baltimore, Maryland.

The second paralysis case indicates that the disease is spreading rapidly, says George Oblapenko, WHO medical officer for polio eradication, based in Copenhagen. The polio virus only causes paralysis in one person in 100 or more infected, and the symptoms are usually mild and transient so each case indicates a far greater problem.

Both of the affected children belong to Bulgaria's gypsy population, the Roma, whose transient lifestyle makes effective vaccination difficult. The WHO has already spearheaded a programme to test and vaccinate children in the immediate area of the infections. Oblapenko says preparations are under way for a massive vaccination effort in the coming weeks targeting around
130,000 Roma children as well as hundreds of thousands of other Bulgarian children under seven years of age.

Oblapenko has praised the quick identification of the cases by Bulgarian health workers. Henderson agrees. "Trying to stop polio is not easy," he says, particularly because so few of those infected show signs of infection.

The Bulgarian cases emphasize the need for countries to maintain not only strong vaccination programmes, but also diligent surveillance even in areas that have had no cases for some time, says Oblapenko. "If you do not protect certain groups of a population, imported wild poliovirus will find the hole, and hit," he says. The girl paralysed in March had not been vaccinated because her doctor decided not to expose her to the vaccine because her general health was weak.

The WHO aims to eradicate polio by around 2005, and then to phase out vaccination because it would theoretically be no longer needed. One step in that plan is to certify regions as virus-free, a classification researchers hope Europe may achieve by early 2002. Because the Bulgarian cases involve importation and do not suggest the persistence of an endemic wild strain in Europe, they will not necessarily block certification. But Oblapenko says it may be delayed.

The goal of eradication has been complicated by the discovery in Hispaniola of polio caused by a vaccine virus strain that mutated to regain its disease-causing ability (see Nature 409, 278-280; 2001). Henderson says that such problems, in conjunction with the Bulgarian outbreak, mean that vaccinations must continue.

But Oblapenko says the WHO's goals will eventually be achieved. "We are pretty sure we will stop [polio]," he says.
Congress hears plan to boost science at environment agency

Tony Reichhardt, Washington

In a move to address criticisms that science at the US Environmental

Protection Agency (EPA) takes a back seat to regulatory politics, a bill to strengthen science at the agency is progressing through the US Congress.

The bill, introduced by Vernon Ehlers (Republican, Michigan), would make environmental research a "central mission" of the EPA and create the post of deputy administrator for science and technology. It was passed unanimously last week by the House Science Committee's environmental subcommittee, which Ehlers chairs.

Ehlers' proposed legislation closely follows advice given in a report on the EPA published by the National Academy of Sciences last autumn. The new deputy administrator would be the agency's chief science adviser, responsible for coordinating the EPA's research portfolio, which at present is overseen by various regulatory offices and field centres. The head of the Office of Research and Development, which sponsors about half of the agency's research, would be designated 'chief scientist' at the EPA and given a five-year term.

The bill now moves to the full science committee for approval. Although it is supported by key legislators, including committee chair Sherwood Boehlert (Republican, New York), the EPA has not endorsed it. Its administrator, Christine Todd Whitman, has said she would prefer to wait until the EPA has completed a review of how science and economics play into its regulatory activities.

Decisions about a new high-level science post are probably secondary to the agency's attempts to get itself elevated to the cabinet. Boehlert recently introduced legislation to that effect, but was forced to withdraw it by the White House, which asked for more time to review its options.

William Glaze, a chemist at the University of North Carolina and chair of the agency's science advisory board, testified in March that the bill would "send a strong signal that the Congress and this administration plan to make science a stronger and more integral part of the way EPA conducts its business."

But the EPA's research budget has remained flat for years. And unless the White House starts listening more closely to the advice of scientists, Glaze says there will be "some scepticism" that a deputy administrator can effect real change. 